\title{
legelivet
}

På disse sidene i Tidsskriftet - legelivet - finner du stoff om legers liv.

Her er det presentasjon av arbeidssteder, nyhetssaker, nye doktorgrader,

nye spesialister og minneord. Alt samlet på ett sted - så du kan følge enda bedre med.

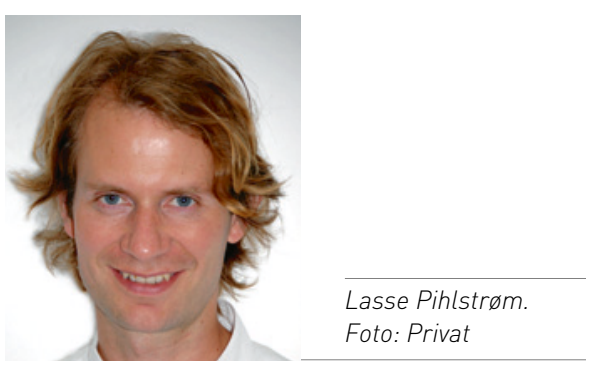

Lasse Pihlstrøm (f. 1980) er stipendiat ved Universitetet i Oslo og lege ved Nevrologisk avdeling, Oslo universitetssykehus.

«Den som måtte ha illusjoner om vitenskapen som en prektig oase av idealisme og ærlighet i en ellers skitten verden, får definitivt noe å tenke på»

\section{Med skjegget i innboksen}

Sorry, Vicky. Det blir ikke oss to.

Jeg er en vitenskapelig eksellense! Å, det er en berusende tanke. Og det står jo svart på hvitt i e-posten: «Vi henvender oss til deg som en fremragende vitenskapsmann innen ditt fagfelt. Vi har fulgt dine publikasjoner og merket oss dine mange imponerende arbeider.» Ja, det er jo nesten sant. Det tok jammen lang tid å få alle kolonnene i den Exel-filen på stell. Og så flikkingen på engelske formuleringer og de lange referanselistene. Det er ensomme greier, men nå har jeg nådd ut!

Det skjedde forbløffende fort, faktisk. Allerede kort tid etter at navnet mitt sto på trykk for første gang, i Tidsskrift for Den norske legeforening, ble jeg jo «oppdaget» der ute. De må ha hatt et eget øye for mitt talent, selv om kasuistikken var på norsk. For invitasjonene begynte raskt å strømme på. Kanskje jeg ville beære det vitenskapelige miljøet med et foredrag i Beijing? Eller hva med en posisjon i redaktørpanelet til et nyoppstartet tidsskrift, dedikert til vitenskap av ypperste kvalitet?

Verden tørster visst etter min ekspertise. Og for en mann av mitt akademiske kaliber er det tydeligvis ikke så nøye om temaet ligger litt i grenselandet for hva jeg har drevet med før. De ville sette umåtelig stor pris på å høre om mine studier av Parkinsons sykdom på dette viktige internasjonale kreftseminaret. Det skriver i hvert fall «Vicky», som ser veldig frem til å møte meg.

Men sorry, Vicky. Det blir nok ikke oss to. Når noe virker altfor godt til å være sant, er det som oftest det. Assosiasjonene går til det legendariske sitatet fra komikeren Groucho Marx: «Jeg ville aldri ønske å tilhøre en klubb som vil ha folk som meg som medlemmer.» $O g$ ved finlesing av e-postene står det aldri noe om at reise og opphold vil bli dekket, aldri noe om honorar for å øse av min visdom. Noen prøver å tjene penger og la meg bli sittende med skjegget $\mathrm{i}$ innboksen.

I oktober 2013 hadde tidsskriftet Science et spesialnummer om «science predators». På norsk ville vi kanskje sagt «vitenskapelige rovdyr/røvere/snyltere». Det er interessant, men nedslående lesning. Den som måtte ha illusjoner om vitenskapen som en prektig oase av idealisme og ærlighet i en ellers skitten verden, får definitivt noe å tenke på. I februar $\mathrm{i}$ år fortalte norske medier om mennesker som får «kjærester» gjennom nettdating og lures til å gi bort store pengesummer. Ofrenes historier illustrerte på tragisk vis hvor sterke psykologiske krefter som ligger i fenomenet ønsketenkning. For hvem drømmer ikke om å bli sett, om å være utvalgt, enten det er i kjærlighet eller vitenskap? Vickys ord varmer, og det er fristende å glemme at hun sannsynligvis er et program som søker opp forskeres e-postadresser og sender ut automatisk generert smisk over hele verden.

Men nå får vi se om du behersker metanivået, Vicky. Får jeg komme til Beijing og snakke om denne fremragende artikkelen i Legelivet?

Lasse Pihlstrøm lasse.pihlstrom@gmail.com 